Review

\title{
Exercise Dosage in Reducing the Risk of Dementia Development: Mode, Duration, and Intensity-A Narrative Review
}

\author{
Sukai Wang ${ }^{1}$ (D) Hong-Yu Liu ${ }^{2}$, Yi-Chen Cheng ${ }^{2}$ iD and Chun-Hsien Su ${ }^{3, *}$ \\ 1 College of Physical Education, Huaqiao University, Quanzhou 362021, China; wsk1019@163.com \\ 2 Department of Exercise and Health Promotion, Chinese Culture University, Taipei 111369, Taiwan; \\ lhy2@ulive.pccu.edu.tw (H.-Y.L.); cyz29@ulive.pccu.edu.tw (Y.-C.C.) \\ 3 College of Kinesiology and Health, Chinese Culture University, Taipei 111369, Taiwan \\ * Correspondence: chsu@ulive.pccu.edu.tw; Tel.: +886-975159678
}

Citation: Wang, S.; Liu, H.-Y.; Cheng, Y.-C.; Su, C.-H. Exercise Dosage in Reducing the Risk of Dementia Development: Mode, Duration, and Intensity-A Narrative Review. Int. J. Environ. Res. Public Health 2021, 18, 13331. https://doi.org/10.3390/ ijerph182413331

Academic Editor: Paul B. Tchounwou

Received: 4 November 2021

Accepted: 13 December 2021

Published: 17 December 2021

Publisher's Note: MDPI stays neutral with regard to jurisdictional claims in published maps and institutional affiliations.

Copyright: (c) 2021 by the authors. Licensee MDPI, Basel, Switzerland. This article is an open access article distributed under the terms and conditions of the Creative Commons Attribution (CC BY) license (https:// creativecommons.org/licenses/by/ $4.0 /)$.

\begin{abstract}
Senile dementia, also known as dementia, is the mental deterioration which is associated with aging. It is characterized by a decrease in cognitive abilities, inability to concentrate, and especially the loss of higher cerebral cortex function, including memory, judgment, abstract thinking, and other loss of personality, even behavior changes. As a matter of fact, dementia is the deterioration of mental and intellectual functions caused by brain diseases in adults when they are mature, which affects the comprehensive performance of life and work ability. Most dementia cases are caused by Alzheimer's disease (AD) and multiple infarct dementia (vascular dementia, multi-infarct dementia). Alzheimer's disease is characterized by atrophy, shedding, and degenerative alterations in brain cells, and its occurrence is linked to age. The fraction of the population with dementia is smaller before the age of 65 , and it increases after the age of 65 . Since women live longer than men, the proportion of women with Alzheimer's disease is higher. Multiple infarct dementia is caused by a cerebral infarction, which disrupts blood supply in multiple locations and impairs cerebral cortex function. Researchers worldwide are investigating ways to prevent Alzheimer's disease; however, currently, there are no definitive answers for Alzheimer's prevention. Even so, research has shown that we can take steps to reduce the risk of developing it. Prospective studies have found that even light to moderate physical activity can lower the risk of dementia and Alzheimer's disease. Exercise has been proposed as a potential lifestyle intervention to help reduce the occurrence of dementia and Alzheimer's disease. Various workout modes will be introduced based on various physical conditions. In general, frequent exercise for 6-8 weeks lessens the risk of dementia development.
\end{abstract}

Keywords: exercise dosage; exercise mode; exercise duration; exercise intensity; physical activity; Alzheimer's disease

\section{Introduction}

Dementia is not a single disease, but a group of symptoms (syndrome). Symptoms include memory loss, and it can affect other cognitive functions, including deterioration of language, spatial sense, computation, judgment, abstract thinking, attention, and other functions [1]. Symptoms such as disruptive behavior, personality changes, delusions or hallucinations may also occur, which are severe enough to affect interpersonal relationships and the ability to work [2]. The linkage of physical activity/exercise and dementia is strong. We will demonstrate the connection in the second section below. In the classification of dementia, there are roughly two categories: degenerative and vascular, but patients sometimes have two or more causes, the most common is Alzheimer's disease and vascular dementia coexist (also known as hybrid) [3,4]. The above two types of dementia are articulated as follows: 


\subsection{Degenerative Dementia}

Most patients fall into this category, among which the following three are the most common.

(1) Alzheimer's disease

It is the most common form of dementia, named after a German doctor, Alois Alzheimer, who discovered it in 1906. In the early stage, the most obvious symptoms are memory decline, problems in the identification of time, place, and people, and more than two kinds of cognitive dysfunction, which is a progressive degradation and irreversible. It is a neurodegenerative disease in which nerve cells in the brain are damaged [5]. Doctors judge through computer tomography and nuclear magnetic resonance that Alzheimer's disease mainly affects the hippocampus in the early stage, and abnormal senile plaques and nerve fiber tangles can be found in the posterior brain anatomy. The clinical course is about $8-10$ years [6].

(2) Frontotemporal lobe degeneration

Brain disorders mainly invade the frontal and temporal lobes, characterized by early personality changes and loss of behavioral control, with patients often having irrational behavior [7]. Alternatively, patients suffer from early onset of language impairment, such as dysphoria, and other gradual declines that occur on average after the age of 50 [8].

(3) Dementia with Lewy bodies

As the second most common degenerative dementia, in addition to the cognitive dysfunction, in early stage, patients may experience stiffness, hand shaking, walking instability, and repeatedly unexplained fall phenomenon. There are also obvious mental symptoms, such as distinct visual or auditory hallucinations mood swings or suspicious delusion symptoms [9].

(4) Others include dementia caused by Huntington's disease and so on

Neurodegenerative dementia is considered as a proteomatosis characterized by the accumulation of specific proteins in the brain, such as beta-amyloid in AD and the microtubule-associated protein tau or alpha-synuclein in Lewy body dementia [10]. Although drugs have not been proven to have a neuroprotective effect on dementia, the growing body of literature demonstrates that long-term, regular exercise has significant benefits on cognition, dementia risk, and dementia progression [11,12].

\subsection{Vascular Dementia}

Vascular dementia is due to stroke or chronic cerebrovascular lesions, resulting in poor blood circulation in the brain. Brain cell death caused by mental decline is the second leading cause of dementia [13]. Generally, vascular dementia occurs after stroke [13]. If a stroke victim survives, roughly $5 \%$ of survivors will develop dementia symptoms. Dementia occurred in $25 \%$ of the cases after five years of surveillance. [14]. Its characteristics are sudden deterioration of cognitive function, ups and downs, step-by-step degradation, slow movement, slow response, gait instability and mental symptoms [13]. Primary vascular dementia is common, and cerebrovascular small vessel diseases too (e.g., white matter osteoporosis and lacunar disease) seem to combine with neurodegenerative processes to cause dementia [15]. These atherosclerotic cerebrovascular mechanisms differ from neurodegeneration and age-related loss of neurofibril networks and synapses [13,16]. Exercise can reduce the effects of atherosclerotic cerebrovascular disease to promote brain health. Since the benefits of exercise in reducing the risk of atherosclerosis (cerebrovascular disease) are well established, exercise may have a more immediate beneficial effect on brain neuroplasticity and resilience to brain aging and neurodegeneration [11,17].

Case-control studies have suggested that increased physical activity can significantly reduce the risk of dementia in older people [18]. In addition, past studies, from the physiological and molecular biological levels of nerve cells, have provided favorable 
evidence that increased physical activity can prevent dementia in older people [19]. Studies have shown that hydrogen peroxide oxidation $\left(\mathrm{H}_{2} \mathrm{O}_{2}\right)$ damage in the body can cause the accumulation of amyloid beta-amyloid (A $\beta)$ and alpha-synuclein ( $\alpha$-syn) in the cells of normally inactive people, which is not the case in endurance athletes [20-22]. Systematic review and meta-analysis studies confirm that the effects of exercise prevention of various types of dementia and Alzheimer's disease show a dose response trend. the greater the amount of physical activity, the better the prevention effect [12].

The decline of the brain's hippocampus and prefrontal cortex, which play important roles in memory formation and complex thinking, is a risk factor for Alzheimer's disease. Surprisingly, these are the same areas that respond to physical activity. Exercise enhances brain growth and prevents cognitive decline. According to a study, older adults who were physically active, even if it was low-intensity activity such as gardening or golf, had larger brains compared to those inactive seniors [18].

\section{The Linkage of Physical Activity/Exercise and Dementia}

Regular physical exercise appears to be one of the effective methods to reduce the risk of dementia among all the lifestyle changes that have been studied [23]. Several studies on the effect of aerobic exercise (exercise that raises your heart rate) in middle-aged or older adults have found improvements in thinking and memory, as well as a reduction in dementia rates [24].

The definition of 'physical activity' or exercise used in research studies in sport science area varies [25]. The American College of Sport Medicine (ACSM) defines physical activity as any bodily movement produced by skeletal muscle contraction that results in a significant increase in caloric requirements over resting energy expenditure [26]. Exercise is a type of physical activity that consists of planned, structured, and repetitive bodily movement that is performed to improve and/or maintain one or more components of physical fitness [27].

\subsection{Increased Physical Activity Can Prevent Cognitive Decline}

Epidemiological generational follow-up studies, case-control studies and systematic retrospective studies have all shown that the risk of Alzheimer's disease, vascular dementia or overall dementia is reduced, regardless of the amount of physical activity, the amount of physical activity during leisure, the amount of total physical activity or the better level of fitness $[11,28,29]$. Increasing physical activity among the elderly has the effect of preventing dementia, and it also has the effect of improving dementia with the help of psycho-emotional aspects such as depression and behavioral and psychological symptoms of dementia (BPSD) [30].

Physical activity may reduce the age-related risk of all-cause dementia in older adults, according to the results of a population-based cohort study presented at the Alzheimer's Association International Conference. The study analyzed data from 8270 participants classified as inactive, low, or moderate-to-vigorous physical activity. Results showed that $7.8 \%$ of participants were diagnosed with all-cause dementia. The risk of all-cause dementia increased by $6.1 \%$ with age. Participants who engaged in low- or moderate-tohigh-intensity physical activity had a reduced risk of all-cause dementia. People aged 80 or older who engaged in moderate to vigorous physical activity had a lower risk of all-cause dementia than inactive adults aged 50 to 69 [31].

People should exercise to mitigate the negative effects of aging on their cognitive function [32]. Physical activity and exercise may slow cognitive decline. The results of several recent randomized controlled trials (RCTS) suggest that physical activity and exercise have positive effects on cognition of people with cognitive decline. The results show that physical activity and exercise can improve the cognitive performance of people with cognitive impairment to some extent [33-35], but it is not clear which combination of frequency, intensity, duration, and type of exercise has a better effect on cognitive performance. To find the best interventions, there is an urgent need to answer the question of how to conduct randomized controlled trials of physical activity and exercise to improve 
cognition of exercise dosages. The study of the dose-response effect of physical activity on cognition of $\mathrm{AD}$ patients is a problem that needs to be solved.

\subsection{Increasing Physical Activity Can Improve Psycho-Emotional Aspects}

In addition to cognitive dysfunction, dementia is often accompanied by emotional, behavioral, psychiatric symptoms and other "non-cognitive symptoms" [36]. These symptoms can cause more discomfort for patients and are a major source of stress for caregivers. "Non-cognitive symptoms" include depression, delusions, confessions, hallucinations, and other mental behavioral disorders [36,37]. Up to 70 to 80 percent of dementia patients develop "non-cognitive symptoms" during their illness.

Different types of dementia are associated with different behavioral and psychiatric symptoms. 1. Alzheimer's disease-common symptoms include apathy, depression, anxiety, delusions, agitation, and impatience [38,39]. 2. Frontotemporal lobe degeneration-the most obvious symptoms are impulsiveness, doing the same thing repeatedly and profanity. They have no sense of sickness. They demonstrate an inability to control behavior and language, and loss of normal social functions at an early age [40]. 3. Dementia with Lewy bodies-there is a higher proportion of behavioral and psychiatric symptoms, about $80 \%$ of patients with vivid visual hallucinations, patients often insist that there are some people at home they do not know, and even talk to them. Not only do they suffer from insomnia, but they may also have REM sleep behavior problems [41].

Exercise helps the brain release endorphins, chemicals that make people feel happy, and studies have shown that regular exercise makes people feel happy for a long period [42]. A study from The Lancet, the world's oldest medical journal, found that those who exercised regularly had 1.5 fewer depressed days per month than those who did not exercise. It also suggested that $45 \mathrm{~min}$ of exercise, three to five times a week provided the greatest benefits for mental health [43]. Michael Miller, a Harvard Medical School PhD, also wrote in a separate article that exercise helps the brain's hippocampus grow, which helps ease depression [44]. In addition to endorphins, many people experience a significant stress relief after exercise because exercise reduces the production of cortisol, the "stress hormone", and adrenalin, which can cause anxiety [45]. Previous studies also found that strength training significantly reduced anxiety symptoms [46,47]. There are several studies that consistently show that exercise leads to greater happiness in both the short and long term, and that increasing physical activity can even improve the mood of people with bipolar disorder the day after exercise, which produces serotonin and makes them feel good $[48,49]$. Studies have also shown that the increase in body temperature during exercise increases blood circulation in the brain and affects the HPA axis (hypothalamic-pituitary-adrenal axis) in the brain, which helps improve mood [50]. In addition, there are many noncognitive, nonvascular degenerative benefits that older people can derive from regular exercise. These include a reduced risk of osteoporosis and fractures, a reduction in age-related sarcopenia, as well as benefits for depression and anxiety. Exercise programs can improve behavioral management of dementia and fall risk [51-56]. Compared with indoor exercise, exercising outdoors in a natural setting can be energizing, reducing stress, anger and depression, and increasing energy levels, researchers say [57]. In addition to improving mood, exercise also improves the brain and central nervous system [57]. Researchers at the University of Texas at Austin have shown that high-intensity exercise improves cognitive performance [58], and another study has shown that moderate-intensity aerobic exercise improves short-term memory [59]. A study at the Georgia Institute of Technology found that just one cycle of strength training already improved memory over $48 \mathrm{~h} \mathrm{[60],} \mathrm{and} \mathrm{another} \mathrm{study} \mathrm{showed} \mathrm{that}$ aerobic exercise had the same effect [61].

\section{Exercise Mode in Reducing the Risk of Dementia Development}

Aerobic (i.e., endurance training), resistance (i.e., strength training), flexibility, and balance are the four main types of exercise training, which may be referred as exercise mode. All people should engage in a variety of physical activities to increase the components of 
physical fitness. Distinct types of physical activities target different aspects of physical fitness that are linked to health.

Physical activity has been shown to reduce the incidence of dementia; however, previous cohort studies have rarely looked at the various types of physical activity and household activities [62]. Physical activity was linked to a lower incidence of dementia in several longitudinal cohort studies, but not all of them [63-65]. Previous studies have been chastised for failing to evaluate the contribution of household activities and for not studying the different types of physical activity [66,67]. Studies have established a link between leisure-time physical exercise and the risk of all-cause dementia or Alzheimer's disease (AD), with the AD risk curve tending to flatten at higher levels of activity [68]. As a result, it is crucial to investigate the risk function's shape and discover the activity level thresholds that correspond to risk changes.

The inverse association between a physically active lifestyle and the risk of cognitive decline is well established, and aerobic exercise training has been the most widely utilized method for investigating the role of physical activity in reducing the detrimental effects of aging on cognitive performance [69].

The various workout modes listed below can be performed alone or in combination with other modes.

1. Aerobic exercises, also known as cardio workouts, are exercises that require movement. Aerobic exercise (also known as endurance activities, cardio, or cardio-respiratory exercise) is a type of low- to moderate-intensity physical activity that relies heavily on the aerobic energy-generating process. This type of exercise is beneficial to the heart and lungs. These workouts help to strengthen the heart and increase lung capacity. Walking, running, dancing, basketball, biking, kickboxing, step-ups or step aerobics, and swimming are the most prevalent forms of these exercises.

2. Muscle development exercises include anaerobic exercises, resistance training, and strength training. Anaerobic exercise is a type of exercise that uses no oxygen to break down glucose in the body. Anaerobic means "without oxygen." In practice, this means that anaerobic exercise is more intense than aerobic exercise but lasts for a shorter time. This type of exercise aids in the development of specific muscle groups. The advantages of this workout include increased muscle strength, size, and endurance. Dumbbell exercises, weightlifting, and using gym equipment are the best examples of these activities.

3. Stretching is performed whenever people experience muscle strain. Stretching is a type of physical activity in which a specific muscle or tendon (or muscle group) is flexed or stretched to improve the muscle's perceived flexibility and attain comfortable muscular tone. Stretching enhances the general flexibility of the body. It may also help to relieve muscle tension and cramps. Yoga, for example, is a methodical stretching and breathing regimen that is good to both the mind and body. It eases anxiety and muscle tension while also expanding your range of motion.

4. Calisthenics, also known as Body Conditioning Workouts, are workouts that do not require the use of any equipment. Calisthenics is a type of strength training that consists of a series of motions that target major muscle groups while using the body's own weight as resistance. The most well-known exercises for this sort of exercise are sit-ups, push-ups, squats, and lunges.

5. Plyometrics are high-intensity workouts which are ideal for athletes and advanced exercisers, as well as exercisers with a well-conditioned body. Plyometrics are exercises that require muscles to exert maximum force for brief periods of time to increase power (speed-strength). Jumping rope, jumping jacks, throwing, and catching a ball against a wall, and boxing with a punching bag are the most typical workouts for this sort from regular exercisers.

Exercise intervention to prevent dementia requires selecting appropriate exercise patterns based on individual health and physical condition, as well as adhering to the 
principles of progressive load, overload, and specificity of exercise training. Targeting previous studies, exercise mode, findings and highlights are listed in Table 1.

Table 1. Exercise mode for dementia prevention.

\begin{tabular}{|c|c|c|c|c|c|}
\hline Title & Cohort & Mode & Findings & Highlights & Reference: Grade \\
\hline \multirow{2}{*}{$\begin{array}{l}\text { Physical activity } \\
\text { types and risk of } \\
\text { dementia in } \\
\text { community-dwelling } \\
\text { older people: the } \\
\text { Three-City cohort }\end{array}$} & \multirow{2}{*}{$\begin{array}{l}n=1550 \\
\text { median age }=80 \\
\text { female participants } \\
=63.6 \%\end{array}$} & $\begin{array}{l}\text { household/ } \\
\text { transportation } \\
\text { activities }\end{array}$ & $\begin{array}{l}\text { dementia was } \\
\text { significantly and } \\
\text { negatively } \\
\text { associated }\end{array}$ & \multirow{2}{*}{$\begin{array}{l}\text { importance of } \\
\text { considering all } \\
\text { physical activity } \\
\text { types in } 72 \text { years } \\
\text { or older people }\end{array}$} & \multirow[t]{2}{*}{ [62]: B } \\
\hline & & $\begin{array}{l}\text { leisure and sport } \\
\text { activity }\end{array}$ & no associated & & \\
\hline \multirow{3}{*}{$\begin{array}{l}\text { Physical activity, } \\
\text { cognitive decline, and } \\
\text { risk of dementia: } \\
\text { 28-year follow-up of } \\
\text { Whitehall II cohort } \\
\text { study }\end{array}$} & \multirow{3}{*}{$\begin{array}{l}n=10,308 \\
\text { age }=35-55 \\
\text { participants = } 6895 \\
\text { men and } 3413 \\
\text { women }\end{array}$} & $\begin{array}{l}\text { mildly energetic } \\
\text { (e.g., weeding, } \\
\text { general } \\
\text { housework, bicycle } \\
\text { repair) }\end{array}$ & $\begin{array}{l}\text { physical activity } \\
\text { does not affect the } \\
\text { risk of dementia }\end{array}$ & \multirow{3}{*}{$\begin{array}{l}\text { 1. Changes in } \\
\text { physical activity } \\
\text { could just be part } \\
\text { of the dementia's } \\
\text { preclinical } \\
\text { symptoms. } \\
\text { 2. There is no } \\
\text { indication that } \\
\text { persons who } \\
\text { engage in more } \\
\text { physical activity } \\
\text { have a reduced } \\
\text { rate of cognitive } \\
\text { deterioration. }\end{array}$} & \multirow{3}{*}{ [63]: B } \\
\hline & & $\begin{array}{l}\text { moderately } \\
\text { energetic (e.g., } \\
\text { dancing, cycling, } \\
\text { leisurely } \\
\text { swimming) }\end{array}$ & $\begin{array}{l}\text { physical activity } \\
\text { does not affect the } \\
\text { risk of dementia }\end{array}$ & & \\
\hline & & $\begin{array}{l}\text { vigorous physical } \\
\text { activity (e.g., } \\
\text { running, hard } \\
\text { swimming, } \\
\text { playing squash) }\end{array}$ & $\begin{array}{l}\text { physical activity } \\
\text { does not affect the } \\
\text { risk of dementia }\end{array}$ & & \\
\hline
\end{tabular}

light (walking,

dancing,

calisthenics, no significant

gardening, more physical

horseback riding) activity is

Physical activity, diet, and risk of Alzheimer disease $n=1880$

mean age $=77.2$

\begin{tabular}{ll}
\hline $\begin{array}{l}\text { Moderate } \\
\text { (bicycling, } \\
\text { swimming, hiking, } \\
\text { playing tennis) }\end{array}$ & $\begin{array}{l}\text { some physical } \\
\text { activity had a 25\% } \\
\text { to } 38 \% \\
\text { lower risk for AD }\end{array}$ \\
\hline $\begin{array}{l}\text { vigorous (aerobic } \\
\text { dancing, jogging, } \\
\text { playing handball) }\end{array}$ & $\begin{array}{l}\text { much physical } \\
\text { to } 48 \% \text { livity had a 33\% } \\
\text { for AD }\end{array}$ \\
\hline
\end{tabular}

walking, hiking, bicycling, aerobics or calisthenics, swimming, water aerobics, weight training or stretching, or other exercise.
Physical exercise and performancebased physical function was statistically significant
Exercise Is Associated with Reduced Risk for Incident Dementia among Persons 65 Years of Age and Older

mean age $=73.2$ (free of dementia) mean age $=78.2$ (with dementia) mean age $=76.3$ (died or withdraw) associated with a reduction in risk for developing $\mathrm{AD}$

physical exercise is associated with delayed onset of [71]: B dementia or Alzheimer disease

$n=1449$

in 1972 age 65-79 years participated in the re-examination in 1998 (mean follow-up, 21 years)
Leisure-time physical activity at midlife at least twice a week was associated with a reduced risk of dementia and AD.
Leisure-time physical activity at midlife is associated with a decreased risk of dementia and $\mathrm{AD}$ later in life.
[72]: A and $\mathrm{Alz}$
disease physical activity 
Table 1. Cont.

\begin{tabular}{|c|c|c|c|c|c|}
\hline Title & Cohort & Mode & Findings & Highlights & Reference: Grade \\
\hline $\begin{array}{l}\text { The Relationship } \\
\text { Between Physical } \\
\text { Activity and } \\
\text { Dementia: A } \\
\text { Systematic Review } \\
\text { and Meta-Analysis of } \\
\text { Prospective Cohort } \\
\text { Studies }\end{array}$ & none & $\begin{array}{l}\text { Vigorous exercise, } \\
\text { regular exercise, } \\
\text { leisure time } \\
\text { physical activities, } \\
\text { and gardening }\end{array}$ & $\begin{array}{l}\text { positive effect } \\
\text { toward lowering } \\
\text { dementia risk }\end{array}$ & $\begin{array}{l}\text { Participation in } \\
\text { physical } \\
\text { activities } \\
\text { produces a } \\
\text { favorable effect } \\
\text { toward lowering } \\
\text { dementia risk. }\end{array}$ & [67]: D \\
\hline $\begin{array}{l}\text { Leisure time physical } \\
\text { activity and dementia } \\
\text { risk: a dose-response } \\
\text { meta-analysis of } \\
\text { prospective studies }\end{array}$ & none & $\begin{array}{l}\text { leisure time } \\
\text { physical activity } \\
\text { (LTPA) }\end{array}$ & $\begin{array}{l}\text { all-cause dementia } \\
\text { or AD exhibited a } \\
\text { linear relationship } \\
\text { with LPTA }\end{array}$ & $\begin{array}{l}\text { the } \\
\text { dose-response } \\
\text { relationship } \\
\text { between LTPA } \\
\text { and dementia, } \\
\text { further } \\
\text { supporting the } \\
\text { international } \\
\text { physical activity } \\
\text { guideline from } \\
\text { the standpoint of } \\
\text { dementia } \\
\text { prevention }\end{array}$ & [68]: D \\
\hline
\end{tabular}

The level of evidence of each reference is graded as A: overwhelming data from randomized controlled trials (RCTs); B: quasi-experimental design; C: results stem from uncontrolled, nonrandomized, and/or observational studies; D: review or evidence in sufficient for categories A to $C$.

According to the findings of these studies, exercise intervention to reduce dementia or Alzheimer's disease has positive implications for lowering the risk of dementia or Alzheimer's disease, with exercise patterns ranging from household activity to prescriptive exercise.

\section{Exercise Duration in Reducing the Risk of Dementia Development}

In 2018, the US Department of Health and Human Services proposed a physical activity key guideline for adults and older adults. The department has specific key recommendations for physical activity duration [26]. Adults and older adults should engage in at least $150 \mathrm{~min}(2 \mathrm{~h}$ and $30 \mathrm{~min}$ ) of moderate-intensity aerobic physical activity per week, or $75 \mathrm{~min}(1 \mathrm{~h}$ and $15 \mathrm{~min})$ to $150 \mathrm{~min}(2 \mathrm{~h}$ and $30 \mathrm{~min}$ ) of vigorous-intensity aerobic physical activity per week, or an equivalent combination of moderate- and vigorous-intensity aerobic activity. Aerobic activity should ideally be spread out over the course of the week. Adults and older adults who are unable to engage in 150 min of moderate-intensity aerobic activity per week due to chronic conditions should be as physically active as their abilities and conditions allow [73].

Several previous studies have looked at physical activity and dementia, as well as the relationship between time spent physically active and dementia. Najar and colleagues created a study about cognitive and physical activity and dementia in which subjects were divided into four groups. Group 1 was completely inactive, spending most of its time watching television and going to the movies. Group 2 engaged in light physical activity for at least $4 \mathrm{~h}$ per week, such as walking, gardening, bowling, or cycling for $30 \mathrm{~min}$ per day. Group 3 engaged in regular physical activity such as running, tennis, or swimming for at least 2-3 h per week. Group 4 received regular-intense physical training, such as heavy exercise, such as running or swimming several times per week, or participation in competitive sports [74]. They discovered that physical activity duration in midlife was associated with a lower risk of mixed dementia and dementia with cerebrovascular disease [74]. A meta-analysis study on the effects of physical activity and exercise on the cognitive function of patients with Alzheimer's disease revealed that all interventions were 
conducted for an average of $40 \mathrm{~min}$ per session, ranging from 30 to $60 \mathrm{~min}$. Interventions lasted at least one hour per week. The total duration ranges from 12 to 24 weeks, with a mean intervention duration of 16.92 weeks. This meta-analysis study, which compared different amounts of physical activity and exercise interventions for Alzheimer's disease in detail, suggested that physical activity and exercise can improve cognition in older adults with Alzheimer's disease [12]. Maass and colleagues investigated the effect of physical activity on cognitive performance in healthy older people and found no significant link between physical activity and cognitive functions. In comparison to other studies, this one only used a 30 min exercise duration; all other studies used physical activities that lasted between 60 and $90 \mathrm{~min}$. The length of the experimental interventions and the duration of the exercise may have played an even larger role in this case. As a result, it can be assumed that $30 \mathrm{~min}$ of exercise (despite the same number of training units per week) may be deemed insufficient in terms of impact on cognitive functions [22].

Previous research has measured physical activity in a variety of ways, examined various types and intensities of activity, and employed a variety of exercise duration and frequency. It has not been possible to provide an optimal exercise prescription for brain health and function, or to reduce the risk of dementia. The good news is that these findings suggest that many types of physical exercise and physical activity are beneficial to brain health and cognitive function when taken together. Table 2 summarizes studies on exercise intervention in dementia in terms of exercise training duration.

Table 2. Exercise duration for dementia prevention.

\begin{tabular}{|c|c|c|c|c|c|}
\hline Title & Cohort & Duration & Findings & Highlights & Reference: Grade \\
\hline $\begin{array}{l}\text { Exercise Dose and } \\
\text { Aerobic Fitness } \\
\text { Response in } \\
\text { Alzheimer's } \\
\text { Dementia in the } \\
\text { FIT-AD Trial }\end{array}$ & $\begin{array}{l}n=67 \\
\text { median age }=77.4 \\
\text { participants }=26 \\
\text { men and } 39 \\
\text { women }\end{array}$ & $\begin{array}{l}\text { 1. First training } \\
\text { stage at } 30 \text { min } \\
\text { 2. Gradually } \\
\text { lengthened to } 60 \\
\text { min } \\
\text { 3. 6-month cycling } \\
\text { aerobic exercise } \\
\text { intervention }\end{array}$ & $\begin{array}{l}\text { aerobic exercise } \\
\text { dose was strongly } \\
\text { and significantly } \\
\text { correlated to } \\
\text { change in peak } \\
\text { oxygen } \\
\text { consumption }\end{array}$ & $\begin{array}{l}\text { Emphasis on } \\
\text { exercise dose is } \\
\text { needed in aerobic } \\
\text { exercise programs } \\
\text { to maximize } \\
\text { cardiorespiratory } \\
\text { fitness gains in } \\
\text { persons with } \\
\text { mild-moderate } \\
\text { Alzheimer's } \\
\text { dementia. }\end{array}$ & [75]: B \\
\hline $\begin{array}{l}\text { Inter-individual } \\
\text { differences in the } \\
\text { responses to } \\
\text { aerobic exercise in } \\
\text { Alzheimer's } \\
\text { disease: Findings } \\
\text { from the FIT-AD } \\
\text { trial }\end{array}$ & $\begin{array}{l}n=78 \\
\text { age }=77.4 \\
\text { participants = } 46 \\
\text { men and } 32 \\
\text { women }\end{array}$ & $\begin{array}{l}\text { 1. First training } \\
\text { stage at } 30 \mathrm{~min} \\
\text { 2. Gradually } \\
\text { lengthened to } \\
60 \mathrm{~min} \\
\text { 3. 6-month aerobic } \\
\text { exercise (cycling } \\
\text { on recumbent } \\
\text { stationary cycles) } \\
\text { program }\end{array}$ & $\begin{array}{l}\text { 1. Individual } \\
\text { differences in } \\
\text { aerobic fitness and } \\
\text { cognitive } \\
\text { responses to } \\
\text { aerobic exercise } \\
\text { 2. No associations } \\
\text { between } \\
\text { attendance and } \\
\text { changes in aerobic } \\
\text { fitness and } \\
\text { cognition }\end{array}$ & $\begin{array}{l}\text { The change in } \\
\text { aerobic fitness } \\
\text { reflects the } \\
\text { collective impact } \\
\text { of aerobic exercise } \\
\text { doses, including } \\
\text { frequency/ } \\
\text { attendance, } \\
\text { intensity, session } \\
\text { duration, and } \\
\text { program duration. }\end{array}$ & [76]: A \\
\hline $\begin{array}{l}\text { Exercise Is } \\
\text { Associated with } \\
\text { Reduced Risk for } \\
\text { Incident Dementia } \\
\text { among Persons } 65 \\
\text { Years of Age and } \\
\text { Older }\end{array}$ & $\begin{array}{l}n=1740 \\
\text { mean age }=73.2 \\
(\text { free of dementia) } \\
\text { mean age }=78.2 \\
(\text { with dementia) } \\
\text { mean age }=76.3 \\
(\text { died or withdraw) }\end{array}$ & $\begin{array}{l}\text { at least } 15 \text { min } \\
\text { (walking, hiking, } \\
\text { bicycling, aerobics } \\
\text { or calisthenics, } \\
\text { swimming, water } \\
\text { aerobics, weight } \\
\text { training or } \\
\text { stretching, or other } \\
\text { exercise) }\end{array}$ & $\begin{array}{l}\text { 1. Moderate } \\
\text { physical activity } \\
\text { had a } 25 \% \text { to } 38 \% \\
\text { lower risk for AD } \\
\text { 2. Much physical } \\
\text { activity had a } 33 \% \\
\text { to } 48 \% \text { lower risk } \\
\text { for AD }\end{array}$ & $\begin{array}{l}\text { more physical } \\
\text { activity is } \\
\text { associated with a } \\
\text { reduction in risk } \\
\text { for developing AD }\end{array}$ & [71]: B \\
\hline
\end{tabular}


Table 2. Cont.

\begin{tabular}{|c|c|c|c|c|c|}
\hline Title & Cohort & Duration & Findings & Highlights & Reference: Grade \\
\hline $\begin{array}{l}\text { A complex } \\
\text { multimodal } \\
\text { activity } \\
\text { intervention to } \\
\text { reduce the risk of } \\
\text { dementia in mild } \\
\text { cognitive } \\
\text { impairment- } \\
\text { Thinking Fit: pilot } \\
\text { and feasibility } \\
\text { study for a } \\
\text { randomized } \\
\text { controlled trial }\end{array}$ & $\begin{array}{l}n=67 \\
\text { mean age }=73.7 \\
\text { participants }=58 \\
\text { men and } 9 \text { women }\end{array}$ & $\begin{array}{l}\text { complete a } \\
\text { minimum of three, } \\
30-45 \text { min physical } \\
\text { activity sessions } \\
\text { per week }\end{array}$ & $\begin{array}{l}\text { Significant } \\
\text { treatment effects } \\
\text { were evident on } \\
\text { physical health } \\
\text { outcomes, fitness, } \\
\text { and cognition. }\end{array}$ & $\begin{array}{l}\text { physical exercises } \\
\text { are associated with } \\
\text { delayed onset of } \\
\text { dementia or } \\
\text { Alzheimer's } \\
\text { disease }\end{array}$ & [77]: B \\
\hline
\end{tabular}

Resistance

Training and

Executive

Functions: A

12-Month

Randomized

Controlled Trial

$$
n=155
$$

mean age $=69.6$
12 months of progressive resistance training once- or twice-weekly
The impact of resistance exercise on the cognitive function of the elderly $n=62$

mean age $=68.15$
1. Three one-hour sessions each week 2. 24 wks. of resistance training
1. Resistance training groups significantly improved their performance on the Stroop Test 2. Task performance improved in the once-weekly and twice-weekly resistance training groups
Twelve months of once-weekly or twice-weekly resistance training benefited the executive cognitive

[78]: A function of selective attention among senior women.
1. Experimental moderate presented higher delta means than the control group for the following tests: digit span forward, Corsi's block-tapping task backward, similarities, and Rey-Osterrieth complex figure immediate recall. 2. Similar for the experimental high group, which showed higher delta means than the control group
Moderate- and

high-intensity resistance exercise programs had [79]: B equally beneficial effects on cognitive functioning. 
Table 2. Cont.

\begin{tabular}{|c|c|c|c|c|c|}
\hline Title & Cohort & Duration & Findings & Highlights & Reference: Grade \\
\hline $\begin{array}{l}\text { Aerobic exercise } \\
\text { and vascular } \\
\text { cognitive } \\
\text { impairment: A } \\
\text { randomized } \\
\text { controlled trial }\end{array}$ & $\begin{array}{l}n=70 \\
\text { mean age }=74\end{array}$ & $\begin{array}{l}\text { 1. Six-month, three- } \\
\text { times-weekly } \\
2 \text {. Each } 60 \text {-min } \\
\text { class included a } \\
\text { 10-min warm-up, a } \\
\text { 40-min walk, and a } \\
\text { 10-min cool down. }\end{array}$ & $\begin{array}{l}\text { Aerobic exercise } \\
\text { training group had } \\
\text { significantly } \\
\text { improved on } \\
\text { Assessment } \\
\text { Scale-Cognitive } \\
\text { subscale } \\
\text { (ADAS-Cog) } \\
\text { performance. }\end{array}$ & $\begin{array}{l}\text { a 6-month } \\
\text { program of } \\
\text { thrice-weekly } \\
\text { progressive aerobic } \\
\text { training promotes } \\
\text { cognitive function } \\
\text { and reduces } \\
\text { cardiovascular risk } \\
\text { in older adults } \\
\text { with mild } \\
\text { sub-cortical } \\
\text { ischemic vascular } \\
\text { cognitive } \\
\text { impairment } \\
\text { (SIVCI) }\end{array}$ & [80]: A \\
\hline
\end{tabular}

The level of evidence of each reference is graded as A: overwhelming data from randomized controlled trials (RCTs); B: quasi-experimental design; C: results stem from uncontrolled, nonrandomized, and/or observational studies; D: review or evidence in sufficient for categories A to $C$.

Non-resistance exercise training typically lasts between 30 and 60 min per exercise intervention, whereas resistance exercise training lasts about an hour per exercise intervention, according to research [71,75-80].

\section{Exercise Intensity in Reducing the Risk of Dementia Development}

The amount of energy expended when exercising is referred to as exercise intensity. Heart rate is commonly used to determine the intensity of exercise. Heart rate can be an indicator of the cardiovascular system's challenge that exercise represents. The most difficult challenge in designing an exercise program is determining the appropriate exercise intensity. HR and rating of perceived exertion (RPE) are the two most used methods for prescribing and monitoring exercise intensity. $\mathrm{HR}$ is used to set an exercise intensity range because there is a linear relationship between $\mathrm{HR}$ and percent functional capacity $\mathrm{VO}_{2}$. For the younger population, exercise intensities of $60-80$ percent are generally recommended. In the elderly, however, an exercise intensity of $40 \%$ of $\mathrm{HR}$ reserve has demonstrated aerobic and functional training adaptations [81].

The Dementia and Physical Activity (DAPA) trial was commissioned by the National Institute for Health Research (NIHR) to inform the debate about the potential benefit of exercise on cognitive impairment in people with dementia [82]. A previous study used longitudinal data to examine the physical activity behavior and cognitive function of 16,700 Europeans aged 54 to 75 over a 13-year period. They discovered that moderate physical activity on a weekly basis has a potential and direct protective effect against cognitive decline and dementia, with women benefiting more than men. A brisk walk is an example of moderate physical activity, whereas running or circuit training is an example of vigorous physical activity [83]. One study, published in the journal Applied Physiology, Nutrition, and Metabolism, in 2019, looked at the link between workout intensity and memory enhancement. Researchers divided a group of 64 elderly participants into three groups: one that did high-intensity interval training, one that did moderate continuous training, and one that did not do any training. While high-intensity interval training improved memory the most, researchers concluded that exercise intensity did not affect executive functioning because positive trends were observed in both exercise groups. The study discovered that general fitness improvement correlated with improved memory performance [84]. Researchers suggest that intensity is critical. Seniors who exercised using short, bursts of activity saw an improvement of up to $30 \%$ in memory performance while participants who worked out moderately saw no improvement, on average [84]. Eleven young men (average age of 25) and ten older men (average age of 69) participated in the study, which was 
published in the journal Medicine \& Science in Sports \& Exercise. The researchers discovered that during interval exercise, there was a greater overall change in the total accumulated volume of blood flow over the duration of both exercise and recovery for both populations than during steady-state exercise. Brain blood flow declines gradually with age and has been linked to the risk of cognitive decline, including dementia. These increases in brain blood flow caused by interval exercise could be beneficial to future brain health [85]. The basis indicators of exercise intensity vary in the research design of an exercise intervention to reduce dementia, ranging from moderate to high intensity. Table 3 organizes the relevant research findings.

Table 3. Exercise intensity for dementia prevention.

\begin{tabular}{|c|c|c|c|c|c|}
\hline Title & Cohort & Intensity & Findings & Highlights & Reference: Grade \\
\hline $\begin{array}{l}\text { The effects of } \\
\text { aerobic exercise } \\
\text { intensity on } \\
\text { memory in older } \\
\text { adults }\end{array}$ & $\begin{array}{l}n=64 \\
\text { median age }=71.96 \\
\text { participants }=39 \\
\text { men and } 25 \\
\text { women }\end{array}$ & $\begin{array}{l}\text { 1. Walked four } \\
4 \text {-min intervals at } \\
5 \% \text { grade and } \\
90-95 \% \text { of peak } \\
\text { heart } \\
\text { rate/intervals } \\
\text { were separated by } \\
\text { 3-min active } \\
\text { recovery periods } \\
\text { (high-intensity } \\
\text { interval training } \\
\text { group/HIIT) } \\
\text { 2. Walking } \\
\text { continuously at } \\
70-75 \% \text { of peak } \\
\text { heart rate for } \\
\text { 47 min (moderate } \\
\text { continuous } \\
\text { training } \\
\text { group/MCT) } \\
\text { 3. Nonaerobic } \\
\text { seated and } \\
\text { standing stretches } \\
\text { group/CON) }\end{array}$ & $\begin{array}{l}\text { 1. High intensity } \\
\text { interval } \\
\text { training(HII) } \\
\text { induced better } \\
\text { memory } \\
\text { performance than } \\
\text { MCT and CON } \\
\text { 2. MCT and CON } \\
\text { were not } \\
\text { significantly } \\
\text { different } \\
\text { 3. increases in } \\
\text { predicted VO } 2 \\
\text { peak was } \\
\text { positively } \\
\text { correlated with } \\
\text { improvements in } \\
\text { high-interference } \\
\text { memory } \\
\text { performance with } \\
\text { a medium effect } \\
\text { size }\end{array}$ & $\begin{array}{l}\text { Aerobic } \\
\text { exercise may } \\
\text { enhance memory } \\
\text { in older adults, } \\
\text { with the potential } \\
\text { for higher intensity } \\
\text { exercise to yield } \\
\text { the greatest benefit }\end{array}$ & [84]: B \\
\hline $\begin{array}{l}\text { High-intensity } \\
\text { interval exercise } \\
\text { improves cognitive } \\
\text { performance and } \\
\text { reduces matrix } \\
\text { metalloproteinases- } \\
2 \text { serum levels in } \\
\text { persons with } \\
\text { multiple sclerosis: } \\
\text { A randomized } \\
\text { controlled trial }\end{array}$ & $\begin{array}{l}n=60 \\
\text { age }=77.4 \\
\text { participants }=46 \\
\text { men and } 32 \\
\text { women }\end{array}$ & $\begin{array}{l}\text { 1. Five times of } \\
\text { 3-min exercise } \\
\text { intervals at } 80 \% \text { of } \\
\text { peak oxygen } \\
\text { uptake } \\
\text { (high-intensity } \\
\text { training } \\
\text { group/HIIT) } \\
\text { 2. } 30 \mathrm{~min} / \text { session } \\
\text { at } 65 \% \text { of peak } \\
\text { oxygen uptake } \\
\text { (control training } \\
\text { group/CT) }\end{array}$ & $\begin{array}{l}\text { 1. HIIT } \\
\text { significantly } \\
\text { improved verbal } \\
\text { memory } \\
2 \text {. HIIT and CT } \\
\text { significantly } \\
\text { improve in } \\
\text { executive functions } \\
\text { 3. Significant } \\
\text { improvements in } \\
\mathrm{VO}_{2} \text {-peak and a } \\
\text { significant } \\
\text { reduction in matrix } \\
\text { metalloproteinases } \\
\text { (MMP)-2 in the } \\
\text { HIIT group only }\end{array}$ & $\begin{array}{l}\text { HIIT represents a } \\
\text { promising strategy } \\
\text { to improve verbal } \\
\text { memory and } \\
\text { physical fitness in } \\
\text { persons with } \\
\text { multiple sclerosis. }\end{array}$ & [86]: A \\
\hline
\end{tabular}


Table 3. Cont.

\begin{tabular}{|c|c|c|c|c|c|}
\hline Title & Cohort & Intensity & Findings & Highlights & Reference: Grade \\
\hline $\begin{array}{l}\text { Aerobic exercise } \\
\text { for Alzheimer's } \\
\text { disease: A } \\
\text { randomized } \\
\text { controlled pilot } \\
\text { trial }\end{array}$ & $\begin{array}{l}n=68 \\
\text { mean age }=72.90 \\
\text { participants }=37 \\
\text { men and } 61 \\
\text { women }\end{array}$ & $\begin{array}{l}\text { target heart rate } \\
\text { (HR) zones from } \\
40-55 \% \text { to } 60-75 \% \\
\text { of HR reserve }\end{array}$ & $\begin{array}{l}\text { 1. When compared } \\
\text { to a stretching and } \\
\text { toning control } \\
\text { intervention, } \\
\text { 6-months of } \\
\text { aerobic exercise } \\
\text { improves } \\
\text { functional ability } \\
\text { in early-stage AD. } \\
\text { 2. Memory } \\
\text { performance and } \\
\text { brain volume } \\
\text { change were } \\
\text { linked to gains in } \\
\text { cardiorespiratory } \\
\text { fitness. }\end{array}$ & $\begin{array}{l}\text { 1. Aerobic exercise } \\
\text { has been linked to } \\
\text { improvements in } \\
\text { functional capacity } \\
\text { in early AD. } \\
\text { 2. Cardiorespiratory } \\
\text { fitness gains may } \\
\text { be important in } \\
\text { driving brain } \\
\text { benefits. }\end{array}$ & [87]: A \\
\hline $\begin{array}{l}\text { Effect of a } \\
\text { High-Intensity } \\
\text { Exercise Program } \\
\text { on Physical } \\
\text { Function and } \\
\text { Mental Health in } \\
\text { Nursing Home } \\
\text { Residents with } \\
\text { Dementia: An } \\
\text { Assessor Blinded } \\
\text { Randomized } \\
\text { Controlled Trial }\end{array}$ & $\begin{array}{l}n=170 \\
\text { mean age }=86.7 \\
\text { participants }=44 \\
\text { men and } 126 \\
\text { women }\end{array}$ & $\begin{array}{l}\text { 1. Strengthening } \\
\text { exercises should be } \\
\text { done for a } \\
\text { maximum of } 12 \\
\text { repetitions (RM) } \\
\text { 2. Control } \\
\text { activities: light } \\
\text { physical activity, } \\
\text { reading, playing } \\
\text { games, listening to } \\
\text { music and } \\
\text { conversations }\end{array}$ & $\begin{array}{l}\text { 1. The intervention } \\
\text { group } \\
\text { outperformed the } \\
\text { control group on } \\
\text { the Bergs Balance } \\
\text { Scale. } \\
\text { 2. Significantly } \\
\text { improved strength } \\
\text { after intervention } \\
\text { 3. Level of apathy } \\
\text { lower in the } \\
\text { exercise group } \\
\text { after the } \\
\text { intervention }\end{array}$ & $\begin{array}{l}\text { The high intensity } \\
\text { functional exercise } \\
\text { program improved } \\
\text { balance and } \\
\text { muscle strength as } \\
\text { well as reduced } \\
\text { apathy in nursing } \\
\text { home patients with } \\
\text { dementia. }\end{array}$ & [88]: A \\
\hline
\end{tabular}

1. Over time, the overall cognitive scores improved.

2. Global cognitive scores not differ between groups in

The Mental

Activity and

exercise (MAX)

Trial

A Randomized

$$
n=126
$$

mean age $=73.4$

participants $=47$

Controlled Trial to

Enhance Cognitive

Function in Older

women

Adults
12 months of progressive resistance training once- or twice-weekly the comparison between mental activity intervention group and mental activity control group

3. Comparison between exercise intervention group and exercise control group no difference
The amount of activity is more

important than the [89]: A type in this subject population 
Table 3. Cont.

\begin{tabular}{|c|c|c|c|c|c|}
\hline Title & Cohort & Intensity & Findings & Highlights & Reference: Grade \\
\hline $\begin{array}{l}\text { Combined } \\
\text { Intervention of } \\
\text { Physical Activity, } \\
\text { Aerobic Exercise, } \\
\text { and Cognitive } \\
\text { Exercise } \\
\text { Intervention to } \\
\text { Prevent Cognitive } \\
\text { Decline for } \\
\text { Patients with Mild } \\
\text { Cognitive } \\
\text { Impairment: A } \\
\text { Randomized } \\
\text { Controlled Clinical } \\
\text { Study }\end{array}$ & $n=49$ & $\begin{array}{l}\text { target heart rate } \\
\text { zone for aerobic } \\
\text { exercise during the } \\
\text { intervention was at } \\
55-80 \% \text { of } \\
\text { maximum heart } \\
\text { rate (HR) }\end{array}$ & $\begin{array}{l}\text { 1. The exercise } \\
\text { group had } \\
\text { significantly better } \\
\text { working memory } \\
\text { and executive } \\
\text { function on the } \\
\text { Assessment } \\
\text { Scale-Cognitive } \\
\text { Subscale } \\
\text { (ADAS-Cog). } \\
\text { 2. Total physical } \\
\text { activity levels were } \\
\text { associated with } \\
\text { improvements in } \\
\text { working memory } \\
\text { function and the } \\
\text { modified } \\
\text { ADAS-Cog score. } \\
\text { 3. The associations } \\
\text { were stronger for } \\
\text { daily moderate } \\
\text { intensity activity } \\
\text { than for daily step } \\
\text { count. }\end{array}$ & $\begin{array}{l}\text { The 24-week } \\
\text { combined } \\
\text { intervention } \\
\text { improved } \\
\text { cognitive function } \\
\text { and physical } \\
\text { function in } \\
\text { patients with mild } \\
\text { cognitive } \\
\text { impairment (MCI) } \\
\text { relative to controls. }\end{array}$ & [90]: A \\
\hline
\end{tabular}

1. When compared

to controls, all exercise groups improved equally in simple attention. 2. A clear In the first 4 weeks dose-response of exercise, the target heart rate zone was $40-55 \%$ of HRR. In Weeks 5-18, it was $50-65 \%$ of HRR. In weeks 19-26, it was $60-75 \%$ of HRR. relationship exist and cardiorespiratory fitness.

3. Cognitive benefits were

$\begin{array}{ll}n=101 & \text { rate zone was } \\ \text { mean age = 72.93 } & 40-55 \% \text { of HRR. In } \\ & \text { Weeks 5-18, it was } \\ & 50-65 \% \text { of HRR. In } \\ & \text { weeks 19-26, it was } \\ & 60-75 \% \text { of HRR. }\end{array}$
between exercise apparent at low doses with possible increased benefits in visuospatial function at higher doses.
An individual's cardiorespiratory fitness response was a better predictor of cognitive gains than exercise dose (i.e., duration) and thus maximizing an individual's cardiorespiratory fitness may be an important therapeutic target for achieving cognitive benefits.
[91]: A

\footnotetext{
The level of evidence of each reference is graded as A: overwhelming data from randomized controlled trials (RCTs); B: quasi-experimental design; C: results stem from uncontrolled, nonrandomized, and/or observational studies; D: review or evidence in sufficient for categories A to $\mathrm{C}$.
}

The exercise intensity in the early studies on the exercise intervention for dementia was mostly set to moderate. In recent years, there has been a gradual increase in highintensity exercise intervention or high-intensity interval exercise intervention, with the exercise intensity being $70-75 \%$ of the maximum heart rate, $80 \%$ of the maximum oxygen consumption, and $60-75 \%$ of the heart rate reserve [84,86-91]. 


\section{Maintain Physical Activity and Exercise Early May Prevent Dementia}

Several studies have found that inactive people have smaller brains, poorer cognitive function, and a decline in structural brain health as they age [92,93]. Experts call for good habits to be formed from the early $20 \mathrm{~s}$ to prevent rapid brain degeneration [93].

\subsection{Homeostasis}

Homeostasis is an important concept that summarizes all aspects of aging from a functional standpoint. Homeostasis refers to the physiological processes that keep the body's internal environment stable [94]. Individuals' ability to tolerate stressors declines as they age, but it is partially modifiable through lifestyle changes. Mueller and Maluf's physical stress theory (PST) capture the essence of homeostasis [95]. The successfully aging older adult has a high tolerance to physiological stressors that challenge homeostasis, whereas the unsuccessfully aging older adult has a low tolerance to physiological stressors that challenge homeostasis. Tolerance range rises in response to exercise and falls in the presence of chronic disease and increased inactivity [94,96]. Exercise results in a strong positive change with systemic adaptation when a person is in homeostasis. Strength and balance, as well as aerobic and muscle endurance, can improve. Positive change occurs when an inactive older adult with stable chronic diseases engages in exercise, albeit more slowly and to a lesser extent $[94,97,98]$.

\subsection{Body Composition}

Over decades, there is a gradual shift in body composition in which lean mass decreases and fat mass increases proportionately, for example, an aging male with a typical shift in fat and lean mass. After the third decade, lean mass, which is mostly muscle, continues to decline. Concurrently, fat mass increases. Body weight has not changed in this individual over the 60 years represented $[94,99,100]$. The fact that most of the fat increase occurs inside the peritoneum, which is now thought to be a significant contributor to the increased inflammation that occurs with age, is significant. Increased intra-abdominal fat is also thought to predispose older people, especially women, to elevated lipids and prediabetes [101]. Fat is a highly active metabolic tissue, and its role in age-related decline and disease is only beginning to be understood. Men and women of all ages who are physically active on a regular basis do not accumulate intra-abdominal fat to the same extent as those who are sedentary [102]. Consequently, active men and women have less whole-body inflammation and less disease [103]. Previous research investigated the relationship between fitness and dementia risk, and the results of brain MRI and cognitive tests revealed that inactive people performed worse on smaller brain volume tests at the age of 60. It was hypothesized that prolonged sitting would reduce brain neurogenesis, angiogenesis, and synaptic plasticity, as well as increase inflammatory responses, all of which would have an impact on brain health $[104,105]$. Obesity is middle age 45 to 60 years old suffering from Alzheimer's disease, one of the risk factors [43]. The accumulation of abdominal fat reduces brain volume, increasing the risk of Alzheimer's disease in the future. Because visceral fat in the abdomen produces more inflammatory cytokines. They are also more likely to have hypertension, diabetes, and cardiovascular disease, which can all lead to vascular brain atrophy and have a negative impact on brain health and cognitive function.

\subsection{Cardiovascular Tissues}

Fundamental changes in vascular tissues that occur with aging are summarized as follows: a decrease in maximum heart rate, a decrease in $\mathrm{VO}_{2} \mathrm{max}$, stiffer, less compliant vascular tissues, loss of cells from the SA node, decreased contractility of the vascular walls, and thickened basement membrane in capillaries. The most noticeable and clinically significant change is the decrease in maximum heart rate $[106,107]$. The typical formula of 220 minus age provides a rough guideline for the expected change in maximum heart rate. Thus, an 80-year-old person is likely to have a maximum heart rate (HRmax) of 
$140 \mathrm{bpm}$, limiting the extent of cardiovascular challenge that can be tolerated for any length of time [108]. There is a link between muscle mass and $\mathrm{VO}_{2} \max$, which is why men have higher max values than women. At any age, the greater the lean mass, the greater the maximal aerobic capacity. Sarcopenia is characterized by a very low aerobic capacity $[109,110]$. Inactivity has been linked to being overweight or obese, type 2 diabetes, certain types of cancer, and premature death in studies. Too much sitting in general, as well as prolonged sitting, appears to increase the risk of death from cardiovascular disease [111]. People with regular exercisers are less likely to suffer from heart disease and stroke, both of which are linked to an increased risk of dementia. Physical activity is also important for maintaining adequate blood flow to the brain and may promote brain cell growth and survival. Exercise is thus one of the factors being researched for its role in lowering the risk of developing dementia as well as the benefits it provides to people with dementia $[112,113]$.

\subsection{Nervous System}

Fundamental changes in the central and peripheral nervous systems have significant implications for function. The following are some of the major age-related changes in the nervous system: Myelin sloughing/loss Slowed nerve conduction, axonal loss, autonomic nervous system dysfunction, sensory neuron loss, and slowed response time are all symptoms of slowed nerve conduction (speed of reaction) [114]. The balance of parasympathetic and sympathetic nervous system output changes with age, which is likely related to slowing gastric motility, bladder control issues, hypertension and hypotension, and deficits in control of blood flow to and from the periphery [115]. In an early study, researchers at the University of Maryland discovered that treadmill walking a 12-week program changes the ability of the brain involved in semantic memory movement after 4 months, the brain in the process of semantic memory test becomes less active, because they can use less response to deal with information. The findings suggest that exercise improves the brain's ability to process semantic memories [116]. According to a study published in Frontiers in Aging Neuroscience, normally healthy older adults who stop exercising for only 10 days or so have brain regions responsible for physical thinking and learning. Blood flow to memory-related areas significantly decreases [117].

In addition to the gradual loss of physical strength and bone mass after the age of 50, the brain shrinks at a rate of 0.5 percent per year beginning at the age of 60 [118]. Continued shrinkage may increase the risk of cognitive impairment or dementia in the future. Many studies have shown that lifestyle patterns in childhood and adolescence influence future brain health, with inactive people having smaller brains, poorer cognitive function, and worse structural health as they age [92,118]. A UCLA study of 35 non-dementia adults aged 45 to 75 published in the journal PLOS ONE in 2018 discovered that prolonged sitting was associated with decreased thickness of the medial temporal lobe, which is responsible for the hippocampus and memory function [104]. It is speculated that prolonged sitting may reduce neurogenesis, angiogenesis, and synaptic plasticity in the brain, and increase inflammation, which affects the health of the hippocampus [119]. A 2015 Boston University study of 1271 adults aged 40 who were followed for 20 years found that inactive people had smaller brains and poorer test results by the time they were 60 , using brain MRI and cognitive tests [120]. Furthermore, in a 2016 study published in JAMA Psychiatry, the Journal of the American Medical Association, 3247 adults aged 18 to 30 were followed for 25 years using three tests to assess cognitive functions such as verbal memory, executive function, and reaction speed, compared to those who exercised more and watched less television [121]. People who exercised less and sat in front of the television for more than three hours per day were more than twice as likely to have poor cognitive function later in life [122]. It is becoming clear that a healthy lifestyle that includes regular exercise can have a significant impact on preventing physical decline and disease. Regular exercisers (at any age) have lower rates of cardiovascular disease, osteoarthritis, diabetes, vascular disease, metabolic syndrome, pain, and Alzheimer's disease, to name a few. 


\section{Conclusions}

Dementia is a type of brain disease that causes a gradual, long-term decline in thinking and memory, impairing a person's ability to function in daily life. Dementia affects 36 million people worldwide, with approximately $10 \%$ developing it during their lifetime.

Dementia can be prevented, and there is a growing body of research demonstrating this. All studies emphasize on changing eating and exercise habits, as well as increasing mental training. Exercise has been shown effective to both prevent and delay the progression of dementia. Aerobic exercise and muscle-strengthening exercises are preferable. Exercise may have a preventive effect due to the neurotrophic factor (BDNF) secreted by the brain, which can prevent hippocampal atrophy and maintain cognitive function. However, because everyone's physical condition differs, the need for preventive measures should differ as well.

The human brain is a very complicated organ. It requires a certain intensity of regular exercise to effectively prevent dementia disease and to achieve real improvement in neural cognitive function and related blood biochemical indexes. The combination of aerobic activity and resistance exercise has a better effect on preventing dementia according to recent abundant researches.

Author Contributions: Conceptualization, S.W. and C.-H.S.; methodology, S.W. and C.-H.S.; validation, Y.-C.C., H.-Y.L. and C.-H.S.; formal analysis, S.W., H.-Y.L. and Y.-C.C.; resources, S.W., H.-Y.L., Y.-C.C. and C.-H.S.; writing-original draft preparation, S.W.; writing-review and editing, Y.-C.C. and C.-H.S.; visualization, H.-Y.L. and Y.-C.C.; supervision, C.-H.S.; project administration, Y.-C.C. All authors have read and agreed to the published version of the manuscript.

Funding: This research received no external funding.

Institutional Review Board Statement: Not applicable.

Informed Consent Statement: Not applicable.

Data Availability Statement: Not applicable.

Conflicts of Interest: The authors declare no conflict of interest.

\section{References}

1. Tarawneh, R.; Holtzman, D.M. The clinical problem of symptomatic Alzheimer disease and mild cognitive impairment. Cold Spring Harb. Perspect. Med. 2012, 2, a006148. [CrossRef] [PubMed]

2. Cerejeira, J.; Lagarto, L.; Mukaetova-Ladinska, E.B. Behavioral and psychological symptoms of dementia. Front. Neurol. 2012, 3 , 73. [CrossRef] [PubMed]

3. National Health Service. Available online: https://www.nhs.uk/conditions/dementia/causes/ (accessed on 5 July 2021).

4. National Institutes of Health. Available online: https://www.nia.nih.gov/health/what-dementia-symptoms-types-anddiagnosis (accessed on 5 July 2021).

5. Karantzoulis, S.; Galvin, J.E. Distinguishing Alzheimer's disease from other major forms of dementia. Expert Rev. Neurother. 2011, 11, 1579-1591. [CrossRef]

6. National Institutes of Health. Available online: https://www.nia.nih.gov/health/alzheimers-disease-fact-sheet (accessed on 5 July 2021).

7. Elahi, F.M.; Miller, B.L. A clinicopathological approach to the diagnosis of dementia. Nat. Rev. Neurol. 2017, 13, 457-476. [CrossRef] [PubMed]

8. Rabinovici, G.D.; Miller, B.L. Frontotemporal lobar degeneration: Epidemiology, pathophysiology, diagnosis and management. CNS Drugs 2010, 24, 375-398. [CrossRef] [PubMed]

9. National Institutes of Health. Available online: https://www.nia.nih.gov/health/what-lewy-body-dementia-causes-symptomsand-treatments (accessed on 5 July 2021).

10. Paleologou, K.E.; Kragh, C.L.; Mann, D.M.; Salem, S.A.; Al-Shami, R.; Allsop, D.; Hassan, A.H.; Jensen, P.H.; El-Agnaf, O.M. Detection of elevated levels of soluble alpha-synuclein oligomers in post-mortem brain extracts from patients with dementia with Lewy bodies. Brain 2009, 132 Pt 4, 1093-1101. [CrossRef] [PubMed]

11. Ahlskog, J.E.; Geda, Y.E.; Graff-Radford, N.R.; Petersen, R.C. Physical exercise as a preventive or disease-modifying treatment of dementia and brain aging. Mayo Clin. Proc. 2011, 86, 876-884. [CrossRef]

12. Jia, R.X.; Liang, J.H.; Xu, Y.; Wang, Y.Q. Effects of physical activity and exercise on the cognitive function of patients with Alzheimer disease: A meta-analysis. BMC Geriatr. 2019, 19, 181. [CrossRef] [PubMed]

13. Iadecola, C. The pathobiology of vascular dementia. Neuron. 2013, 80, 844-866. [CrossRef] [PubMed] 
14. Corraini, P.; Henderson, V.W.; Ording, A.G.; Pedersen, L.; Horváth-Puhó, E.; Sørensen, H.T. Long-Term Risk of Dementia Among Survivors of Ischemic or Hemorrhagic Stroke. Stroke 2017, 48, 180-186. [CrossRef] [PubMed]

15. Kalaria, R.N.; Erkinjuntti, T. Small vessel disease and subcortical vascular dementia. J. Clin. Neurol. 2006, 2, 1-11. [CrossRef] [PubMed]

16. Kalaria, R.N. Neuropathological diagnosis of vascular cognitive impairment and vascular dementia with implications for Alzheimer's disease. Acta Neuropathol. 2016, 131, 659-685. [CrossRef] [PubMed]

17. Duzel, E.; van Praag, H.; Sendtner, M. Can physical exercise in old age improve memory and hippocampal function? Brain 2016, 139 Pt 3, 662-673. [CrossRef] [PubMed]

18. Gregory, S.M.; Parker, B.; Thompson, P.D. Physical activity, cognitive function, and brain health: What is the role of exercise training in the prevention of dementia? Brain Sci. 2012, 2, 684-708. [CrossRef]

19. Brown, B.M.; Peiffer, J.J.; Martins, R.N. Multiple effects of physical activity on molecular and cognitive signs of brain aging: Can exercise slow neurodegeneration and delay Alzheimer's disease? Mol. Psychiatry 2013, 18, 864-874. [CrossRef] [PubMed]

20. De la Rosa, A.; Olaso-Gonzalez, G.; Arc-Chagnaud, C.; Millan, F.; Salvador-Pascual, A.; García-Lucerga, C.; Blasco-Lafarga, C.; Garcia-Dominguez, E.; Carretero, A.; Correas, A.G.; et al. Physical exercise in the prevention and treatment of Alzheimer's disease. J. Sport Health Sci. 2020, 9, 394-404. [CrossRef]

21. Nichol, K.E.; Poon, W.W.; Parachikova, A.I.; Cribbs, D.H.; Glabe, C.G.; Cotman, C.W. Exercise alters the immune profile in Tg2576 Alzheimer mice toward a response coincident with improved cognitive performance and decreased amyloid. J. Neuroinflamm. 2008, 5, 13. [CrossRef] [PubMed]

22. Maass, A.; Düzel, S.; Brigadski, T.; Goerke, M.; Becke, A.; Sobieray, U.; Neumann, K.; Lövdén, M.; Lindenberger, U.; Bäckman, L.; et al. Relationships of peripheral IGF-1, VEGF and BDNF levels to exercise-related changes in memory, hippocampal perfusion and volumes in older adults. NeuroImage 2016, 131, 142-154. [CrossRef] [PubMed]

23. Alty, J.; Farrow, M.; Lawler, K. Exercise and dementia prevention. Pract. Neurol. 2020, 20, 234-240. [CrossRef] [PubMed]

24. Tarumi, T.; Rossetti, H.; Thomas, B.P.; Harris, T.; Tseng, B.Y.; Turner, M.; Wang, C.; German, Z.; Martin-Cook, K.; Stowe, A.M.; et al. Exercise Training in Amnestic Mild Cognitive Impairment: A One-Year Randomized Controlled Trial. J. Alzheimers Dis. 2019, 71, 421-433. [CrossRef]

25. Piggin, J. What Is Physical Activity? A Holistic Definition for Teachers, Researchers and Policy Makers. Front. Sports Act. Living 2020, 2, 72. [CrossRef] [PubMed]

26. American College of Sports Medicine [ACSM]. ACSM's Guidelines for Exercise Testing and Prescription, 10th ed.; Lippincott Williams \& Wilkins: Baltimore, MD, USA, 2018.

27. Caspersen, C.J.; Powell, K.E.; Christenson, G.M. Physical activity, exercise, and physical fitness: Definitions and distinctions for health-related research. Public Health Rep. 1985, 100, 126-131. [PubMed]

28. Blondell, S.J.; Hammersley-Mather, R.; Veerman, J.L. Does physical activity prevent cognitive decline and dementia? A systematic review and meta-analysis of longitudinal studies. BMC Public Health 2014, 14, 510. [CrossRef]

29. Guure, C.B.; Ibrahim, N.A.; Adam, M.B.; Said, S.M. Impact of Physical Activity on Cognitive Decline, Dementia, and Its Subtypes: Meta-Analysis of Prospective Studies. BioMed Res. Int. 2017, 2017, 9016924. [CrossRef] [PubMed]

30. Heyn, P.; Abreu, B.C.; Ottenbacher, K.J. The effects of exercise training on elderly persons with cognitive impairment and dementia: A meta-analysis. Arch. Phys. Med. Rehabil. 2004, 85, 1694-1704. [CrossRef] [PubMed]

31. Feter, N.; Dumith, S.C.; Smith, E.C.; da Cunha, L.L.; Cassuriaga, J.; Leite, J.S.; Alt, R.; Coombes, J.S.; Rombaldi, A.J. Physical activity attenuates the risk for dementia associated with aging in older adults with mild cognitive impairment. Findings from a population-based cohort study. J. Psychiatr. Res. 2021, 141, 1-8. [CrossRef] [PubMed]

32. Colcombe, S.J.; Erickson, K.I.; Scalf, P.E.; Kim, J.S.; Prakash, R.; McAuley, E.; Elavsky, S.; Marquez, D.X.; Hu, L.; Kramer, A.F Aerobic exercise training increases brain volume in aging humans. J. Gerontol. Ser. A 2006, 61, 1166-1170. [CrossRef] [PubMed]

33. Erickson, K.I.; Voss, M.W.; Prakash, R.S.; Basak, C.; Szabo, A.; Chaddock, L.; Kim, J.S.; Heo, S.; Alves, H.; White, S.M.; et al. Exercise training increases size of hippocampus and improves memory. Proc. Natl. Acad. Sci. USA 2011, 108, $3017-3022$. [CrossRef] [PubMed]

34. Douw, L.; Nieboer, D.; van Dijk, B.W.; Stam, C.J.; Twisk, J.W. A healthy brain in a healthy body: Brain network correlates of physical and mental fitness. PLoS ONE 2014, 9, e88202. [CrossRef] [PubMed]

35. Niemann, C.; Godde, B.; Staudinger, U.M.; Voelcker-Rehage, C. Exercise-induced changes in basal ganglia volume and cognition in older adults. Neuroscience 2014, 281, 147-163. [CrossRef] [PubMed]

36. Aalten, P.; de Vugt, M.E.; Lousberg, R.; Korten, E.; Jaspers, N.; Senden, B.; Jolles, J.; Verhey, F.R. Behavioral problems in dementia: A factor analysis of the neuropsychiatric inventory. Dement Geriatr Cogn Disord. 2003, 15, 99-105. [CrossRef] [PubMed]

37. Forester, B.P.; Oxman, T.E. Measures to Assess the Noncognitive Symptoms of Dementia in the Primary Care Setting. Prim. Care Companion J. Clin. Psychiatry 2003, 5, 158-163. [CrossRef] [PubMed]

38. Onyike, C.U. Psychiatric Aspects of Dementia. Continuum 2016, 22, 600-614. [CrossRef]

39. Lyketsos, C.G.; Carrillo, M.C.; Ryan, J.M.; Khachaturian, A.S.; Trzepacz, P.; Amatniek, J.; Cedarbaum, J.; Brashear, R.; Miller, D.S. Neuropsychiatric symptoms in Alzheimer's disease. Alzheimers Dement. 2011, 7, 532-539. [CrossRef]

40. Johns Hopkins Medicine. Available online: https://www.hopkinsmedicine.org/health/conditions-and-diseases/dementia/ frontotemporal-dementia (accessed on 25 July 2021). 
41. National Institutes of Health. Available online: https://www.ninds.nih.gov/Disorders/Patient-Caregiver-Education/HopeThrough-Research/Lewy-Body-Dementia-Hope-Through-Research (accessed on 25 July 2021).

42. Chen, W.W.; Zhang, X.; Huang, W.J. Role of physical exercise in Alzheimer's disease. Biomed. Rep. 2016, 4, 403-407. [CrossRef] [PubMed]

43. Chekroud, S.R.; Gueorguieva, R.; Zheutlin, A.B.; Paulus, M.; Krumholz, H.M.; Krystal, J.H.; Chekroud, A.M. Association between physical exercise and mental health in 1.2 million individuals in the USA between 2011 and 2015: A cross-sectional study. Lancet Psychiatry 2018, 5, 739-746. [CrossRef]

44. Harvard Health Publishing, Harvard Medical School. Available online: https://www.health.harvard.edu/mind-and-mood/ exercise-is-an-all-natural-treatment-to-fight-depression (accessed on 25 July 2021).

45. Hill, E.E.; Zack, E.; Battaglini, C.; Viru, M.; Viru, A.; Hackney, A.C. Exercise and circulating cortisol levels: The intensity threshold effect. J. Endocrinol. Investig. 2008, 31, 587-591. [CrossRef] [PubMed]

46. Gordon, B.R.; McDowell, C.P.; Lyons, M.; Herring, M.P. The Effects of Resistance Exercise Training on Anxiety: A Meta-Analysis and Meta-Regression Analysis of Randomized Controlled Trials. Sports Med. 2017, 47, 2521-2532. [CrossRef] [PubMed]

47. Stubbs, B.; Vancampfort, D.; Rosenbaum, S.; Firth, J.; Cosco, T.; Veronese, N.; Salum, G.A.; Schuch, F.B. An examination of the anxiolytic effects of exercise for people with anxiety and stress-related disorders: A meta-analysis. Psychiatry Res. 2017, 249, 102-108. [CrossRef] [PubMed]

48. O'Connor, P.J.; Herring, M.P.; Caravalho, A. Mental Health Benefits of Strength Training in Adults. Am. J. Lifestyle Med. 2010, 4, 377-396. [CrossRef]

49. Koščak Tivadar, B. Physical activity improves cognition: Possible explanations. Biogerontology 2017, 18, 477-483. [CrossRef]

50. Basso, J.C.; Suzuki, W.A. The Effects of Acute Exercise on Mood, Cognition, Neurophysiology, and Neurochemical Pathways: A Review. Brain Plast. 2017, 2, 127-152. [CrossRef] [PubMed]

51. Rizzoli, R.; Bruyère, O.; Cannata-Andia, J.B.; Devogelaer, J.P.; Lyritis, G.; Ringe, J.D.; Vellas, B.; Reginster, J.Y. Management of osteoporosis in the elderly. Curr. Med. Res. Opin. 2009, 25, 2373-2387. [CrossRef] [PubMed]

52. Thomas, D.R. Sarcopenia. Clin. Geriatr. Med. 2010, 26, 331-346. [CrossRef]

53. Conn, V.S. Depressive symptom outcomes of physical activity interventions: Meta-analysis findings. Ann. Behav. Med. 2010, 39, 128-138. [CrossRef]

54. Dunn, A.L. Review: Exercise programmes reduce anxiety symptoms in sedentary patients with chronic illnesses. Evid.-Based. Ment. Health 2010, 13, 95. [CrossRef] [PubMed]

55. Teri, L.; Gibbons, L.E.; McCurry, S.M.; Logsdon, R.G.; Buchner, D.M.; Barlow, W.E.; Kukull, W.A.; LaCroix, A.Z.; McCormick, W.; Larson, E.B. Exercise plus behavioral management in patients with Alzheimer disease: A randomized controlled trial. JAMA 2003, 290, 2015-2022. [CrossRef] [PubMed]

56. Allan, L.M.; Ballard, C.G.; Rowan, E.N.; Kenny, R.A. Incidence and prediction of falls in dementia: A prospective study in older people. PLoS ONE 2009, 4, e5521. [CrossRef] [PubMed]

57. Gladwell, V.F.; Brown, D.K.; Wood, C.; Sandercock, G.R.; Barton, J.L. The great outdoors: How a green exercise environment can benefit all. Extrem. Physiol. Med. 2013, 2, 3. [CrossRef] [PubMed]

58. Hwang, J.; Brothers, R.M.; Castelli, D.M.; Glowacki, E.M.; Chen, Y.T.; Salinas, M.M.; Kim, J.; Jung, Y.; Calvert, H.G. Acute high-intensity exercise-induced cognitive enhancement and brain-derived neurotrophic factor in young, healthy adults. Neurosci. Lett. 2016, 630, 247-253. [CrossRef] [PubMed]

59. Marchant, D.; Hampson, S.; Finnigan, L.; Marrin, K.; Thorley, C. The Effects of Acute Moderate and High Intensity Exercise on Memory. Front. Psychol. 2020, 11, 1716. [CrossRef] [PubMed]

60. Weinberg, L.; Hasni, A.; Shinohara, M.; Duarte, A. A single bout of resistance exercise can enhance episodic memory performance. Acta Psychol. 2014, 153, 13-19. [CrossRef]

61. Guadagni, V.; Drogos, L.L.; Tyndall, A.V.; Davenport, M.H.; Anderson, T.J.; Eskes, G.A.; Longman, R.S.; Hill, M.D.; Hogan, D.B.; Poulin, M.J. Aerobic exercise improves cognition and cerebrovascular regulation in older adults. Neurology 2020, 94, e2245-e2257. [CrossRef]

62. Dupré, C.; Bongue, B.; Helmer, C.; Dartigues, J.F.; Hupin, D.; Roche, F.; Berr, C.; Carrière, I. Physical activity types and risk of dementia in community-dwelling older people: The Three-City cohort. BMC Geriatr. 2020, 20, 132. [CrossRef] [PubMed]

63. Sabia, S.; Dugravot, A.; Dartigues, J.F.; Abell, J.; Elbaz, A.; Kivimäki, M.; Singh-Manoux, A. Physical activity, cognitive decline, and risk of dementia: 28 year follow-up of Whitehall II cohort study. BMJ 2017, 357, j2709. [CrossRef]

64. Wilson, R.S.; Mendes De Leon, C.F.; Barnes, L.L.; Schneider, J.A.; Bienias, J.L.; Evans, D.A.; Bennett, D.A. Participation in cognitively stimulating activities and risk of incident Alzheimer disease. JAMA 2002, 287, 742-748. [CrossRef] [PubMed]

65. Yamada, M.; Kasagi, F.; Sasaki, H.; Masunari, N.; Mimori, Y.; Suzuki, G. Association between dementia and midlife risk factors: The Radiation Effects Research Foundation Adult Health Study. J. Am. Geriatr. Soc. 2003, 51, 410-414. [CrossRef]

66. Stephen, R.; Hongisto, K.; Solomon, A.; Lönnroos, E. Physical Activity and Alzheimer's Disease: A Systematic Review. J. Gerontol. Ser. A 2017, 72, 733-739. [CrossRef] [PubMed]

67. Lee, J. The Relationship between Physical Activity and Dementia: A Systematic Review and Meta-Analysis of Prospective Cohort Studies. J. Gerontol. Nurs. 2018, 44, 22-29. [CrossRef] [PubMed]

68. Xu, W.; Wang, H.F.; Wan, Y.; Tan, C.C.; Yu, J.T.; Tan, L. Leisure time physical activity and dementia risk: A dose-response meta-analysis of prospective studies. BMJ Open 2017, 7, e014706. [CrossRef] [PubMed] 
69. Laurin, D.; Verreault, R.; Lindsay, J.; MacPherson, K.; Rockwood, K. Physical activity and risk of cognitive impairment and dementia in elderly persons. Arch. Neurol. 2001, 58, 498-504. [CrossRef] [PubMed]

70. Piercy, K.L.; Troiano, R.P.; Ballard, R.M.; Carlson, S.A.; Fulton, J.E.; Galuska, D.A.; George, S.M.; Olson, R.D. The Physical Activity Guidelines for Americans. JAMA 2018, 320, 2020-2028. [CrossRef] [PubMed]

71. Najar, J.; Östling, S.; Gudmundsson, P.; Sundh, V.; Johansson, L.; Kern, S.; Guo, X.; Hällström, T.; Skoog, I. Cognitive and physical activity and dementia: A 44-year longitudinal population study of women. Neurology 2019, 92, e1322-e1330. [CrossRef] [PubMed]

72. Exercise Considerations for Aging Adults. Available online: https://musculoskeletalkey.com/exercise-considerations-for-agingadults / (accessed on 28 July 2021).

73. Lamb, S.E.; Sheehan, B.; Atherton, N.; Nichols, V.; Collins, H.; Mistry, D.; Dosanjh, S.; Slowther, A.M.; Khan, I.; Petrou, S.; et al. Dementia and Physical Activity (DAPA) trial of moderate to high intensity exercise training for people with dementia: Randomised controlled trial. BMJ 2018, 361, k1675. [CrossRef] [PubMed]

74. Lenzen, S.; Gannon, B.; Rose, C. A dynamic microeconomic analysis of the impact of physical activity on cognition among older people. Econ. Hum. Biol. 2020, 39, 100933. [CrossRef] [PubMed]

75. Kovacevic, A.; Fenesi, B.; Paolucci, E.; Heisz, J.J. The effects of aerobic exercise intensity on memory in older adults. Appl. Physiol. Nutr. Metab. 2020, 45, 591-600. [CrossRef]

76. Klein, T.; Bailey, T.G.; Abeln, V.; Schneider, S.; Askew, C.D. Cerebral Blood Flow during Interval and Continuous Exercise in Young and Old Men. Med. Sci. Sports Exerc. 2019, 51, 1523-1531. [CrossRef]

77. Mintzer, J.; Donovan, K.A.; Kindy, A.Z.; Lock, S.L.; Chura, L.R.; Barracca, N. Lifestyle Choices and Brain Health. Front. Med. 2019, 6, 204. [CrossRef] [PubMed]

78. Risk Reduction of Cognitive Decline and Dementia: WHO Guidelines. Available online: https://apps.who.int/iris/bitstream/ handle/10665/312180/9789241550543-eng.pdf (accessed on 30 July 2021).

79. Pomatto, L.C.D.; Davies, K.J.A. The role of declining adaptive homeostasis in ageing. J. Physiol. 2017, 595, 7275-7309. [CrossRef] [PubMed]

80. Mueller, M.J.; Maluf, K.S. Tissue adaptation to physical stress: A proposed "Physical Stress Theory" to guide physical therapist practice, education, and research. Phys. Ther. 2002, 82, 383-403. [CrossRef] [PubMed]

81. Boss, G.R.; Seegmiller, J.E. Age-related physiological changes and their clinical significance. West J Med. 1981, 135, 434-440. [PubMed]

82. Runkel, E.D.; Liu, S.; Baumeister, R.; Schulze, E. Surveillance-activated defenses block the ROS-induced mitochondrial unfolded protein response. PLoS Genet. 2013, 9, e1003346. [CrossRef]

83. Holviala, J.; Häkkinen, A.; Alen, M.; Sallinen, J.; Kraemer, W.; Häkkinen, K. Effects of prolonged and maintenance strength training on force production, walking, and balance in aging women and men. Scand. J. Med. Sci. Sports 2014, 24, 224-233. [CrossRef] [PubMed]

84. St-Onge, M.P.; Gallagher, D. Body composition changes with aging: The cause or the result of alterations in metabolic rate and macronutrient oxidation? Nutrition 2010, 26, 152-155. [CrossRef] [PubMed]

85. Santanasto, A.J.; Goodpaster, B.H.; Kritchevsky, S.B.; Miljkovic, I.; Satterfield, S.; Schwartz, A.V.; Cummings, S.R.; Boudreau, R.M.; Harris, T.B.; Newman, A.B. Body Composition Remodeling and Mortality: The Health Aging and Body Composition Study. J. Gerontol. Ser. A 2017, 72, 513-519. [CrossRef] [PubMed]

86. Ferraro, F.R.; Muehlenkamp, J.J.; Paintner, A.; Wasson, K.; Hager, T.; Hoverson, F. Aging, body image, and body shape. J. Gen. Psychol. 2008, 135, 379-392. [CrossRef] [PubMed]

87. Baumgartner, R.N.; Koehler, K.M.; Gallagher, D.; Romero, L.; Heymsfield, S.B.; Ross, R.R.; Garry, P.J.; Lindeman, R.D. Epidemiology of sarcopenia among the elderly in New Mexico. Am. J. Epidemiol. 1998, 147, 755-763. [CrossRef]

88. Frontera, W.R.; Hughes, V.A.; Lutz, K.J.; Evans, W.J. A cross-sectional study of muscle strength and mass in 45- to 78-yr-old men and women. J. Appl. Physiol. 1991, 71, 644-650. [CrossRef]

89. Tan, Z.S.; Spartano, N.L.; Beiser, A.S.; DeCarli, C.; Auerbach, S.H.; Vasan, R.S.; Seshadri, S. Physical Activity, Brain Volume, and Dementia Risk: The Framingham Study. J. Gerontol. Ser. A 2017, 72, 789-795. [CrossRef] [PubMed]

90. Spartano, N.L.; Ngandu, T. Fitness and dementia risk: Further evidence of the heart-brain connection. Neurology 2018, 90, 675-676. [CrossRef] [PubMed]

91. Fleg, J.L.; Strait, J. Age-associated changes in cardiovascular structure and function: A fertile milieu for future disease. Heart Fail. Rev. 2012, 17, 545-554. [CrossRef] [PubMed]

92. Ungvari, Z.; Tarantini, S.; Donato, A.J.; Galvan, V.; Csiszar, A. Mechanisms of Vascular Aging. Circ. Res. 2018, 123, 849-867. [CrossRef] [PubMed]

93. Target Heart Rate and Estimated Maximum Heart Rate. Available online: https://www.cdc.gov/physicalactivity/basics/ measuring/heartrate.htm (accessed on 30 July 2021).

94. Eskurza, I.; Donato, A.J.; Moreau, K.L.; Seals, D.R.; Tanaka, H. Changes in maximal aerobic capacity with age in endurance-trained women: 7-yr follow-up. J. Appl. Physiol. 2002, 92, 2303-2308. [CrossRef] [PubMed]

95. Maciejczyk, M.; Więcek, M.; Szymura, J.; Szyguła, Z.; Wiecha, S.; Cempla, J. The influence of increased body fat or lean body mass on aerobic performance. PLoS ONE 2014, 9, e95797. [CrossRef] [PubMed] 
96. Hamilton, M.T.; Healy, G.N.; Dunstan, D.W.; Zderic, T.W.; Owen, N. Too Little Exercise and Too Much Sitting: Inactivity Physiology and the Need for New Recommendations on Sedentary Behavior. Curr. Cardiovasc. Risk Rep. 2008, 2, $292-298$. [CrossRef]

97. Pinckard, K.; Baskin, K.K.; Stanford, K.I. Effects of Exercise to Improve Cardiovascular Health. Front. Cardiovasc. Med. 2019, 6, 69. [CrossRef] [PubMed]

98. Paillard, T. Preventive effects of regular physical exercise against cognitive decline and the risk of dementia with age advancement. Sports Med. Open 2015, 1, 20. [CrossRef] [PubMed]

99. Sorond, F.A.; Cruz-Almeida, Y.; Clark, D.J.; Viswanathan, A.; Scherzer, C.R.; De Jager, P.; Csiszar, A.; Laurienti, P.J.; Hausdorff, J.M.; Chen, W.G.; et al. Aging, the Central Nervous System, and Mobility in Older Adults: Neural Mechanisms of Mobility Impairment. J. Gerontol. Ser. A 2015, 70, 1526-1532. [CrossRef]

100. McCorry, L.K. Physiology of the autonomic nervous system. Am. J. Pharm. Educ. 2007, 71, 78. [CrossRef] [PubMed]

101. Smith, J.C.; Nielson, K.A.; Antuono, P.; Lyons, J.A.; Hanson, R.J.; Butts, A.M.; Hantke, N.C.; Verber, M.D. Semantic memory functional MRI and cognitive function after exercise intervention in mild cognitive impairment. J. Alzheimers. Dis. 2013, 37, 197-215. [CrossRef]

102. Castells-Sánchez, A.; Roig-Coll, F.; Lamonja-Vicente, N.; Altés-Magret, M.; Torán-Monserrat, P.; Via, M.; García-Molina, A.; Tormos, J.M.; Heras, A.; Alzamora, M.T.; et al. Effects and Mechanisms of Cognitive, Aerobic Exercise, and Combined Training on Cognition, Health, and Brain Outcomes in Physically Inactive Older Adults: The Projecte Moviment Protocol. Front. Aging Neurosci. 2019, 11, 216. [CrossRef] [PubMed]

103. Padilla Colón, C.J.; Molina-Vicenty, I.L.; Frontera-Rodríguez, M.; García-Ferré, A.; Rivera, B.P.; Cintrón-Vélez, G.; FronteraRodríguez, S. Muscle and Bone Mass Loss in the Elderly Population: Advances in diagnosis and treatment. J. Biomed. 2018, 3 , 40-49. [CrossRef] [PubMed]

104. Siddarth, P.; Burggren, A.C.; Eyre, H.A.; Small, G.W.; Merrill, D.A. Sedentary behavior associated with reduced medial temporal lobe thickness in middle-aged and older adults. PLoS ONE 2018, 13, e0195549. [CrossRef] [PubMed]

105. Better Midlife Fitness May Slow Brain Aging. Available online: https://news.heart.org/better-midlife-fitness-may-slow-brainaging/ (accessed on 31 July 2021).

106. Hoang, T.D.; Reis, J.; Zhu, N.; Jacobs, D.R.; Launer, L.J.; Whitmer, R.A.; Sidney, S.; Yaffe, K. Effect of Early Adult Patterns of Physical Activity and Television Viewing on Midlife Cognitive Function. JAMA Psychiatry 2016, 73, 73-79. [CrossRef] [PubMed]

107. Fancourt, D.; Steptoe, A. Television viewing and cognitive decline in older age: Findings from the English Longitudinal Study of Ageing. Sci. Rep. 2019, 9, 2851. [CrossRef] [PubMed]

108. Scarmeas, N.; Luchsinger, J.A.; Schupf, N.; Brickman, A.M.; Cosentino, S.; Tang, M.X.; Stern, Y. Physical activity, diet, and risk of Alzheimer disease. JAMA 2009, 302, 627-637. [CrossRef]

109. Larson, E.B.; Wang, L.; Bowen, J.D.; McCormick, W.C.; Teri, L.; Crane, P.; Kukull, W. Exercise is associated with reduced risk for incident dementia among persons 65 years of age and older. Ann. Intern. Med. 2006, 144, 73-81. [CrossRef] [PubMed]

110. Rovio, S.; Kåreholt, I.; Helkala, E.L.; Viitanen, M.; Winblad, B.; Tuomilehto, J.; Soininen, H.; Nissinen, A.; Kivipelto, M. Leisure-time physical activity at midlife and the risk of dementia and Alzheimer's disease. Lancet Neurol. 2005, 4, 705-711. [CrossRef]

111. Salisbury, D.; Mathiason, M.A.; Yu, F. Exercise Dose and Aerobic Fitness Response in Alzheimer's Dementia in the FIT-AD Trial. Int. J. Sports Med. ahead of print. 2021. [CrossRef]

112. Yu, F.; Salisbury, D.; Mathiason, M.A. Inter-individual differences in the responses to aerobic exercise in Alzheimer's disease: Findings from the FIT-AD trial. J. Sport Health Sci. 2021, 10, 65-72. [CrossRef] [PubMed]

113. Dannhauser, T.M.; Cleverley, M.; Whitfield, T.J.; Fletcher, B.C.; Stevens, T.; Walker, Z. A complex multimodal activity intervention to reduce the risk of dementia in mild cognitive impairment-ThinkingFit: Pilot and feasibility study for a randomized controlled trial. BMC Psychiatry 2014, 14, 129. [CrossRef]

114. Liu-Ambrose, T.; Nagamatsu, L.S.; Graf, P.; Beattie, B.L.; Ashe, M.C.; Handy, T.C. Resistance training and executive functions: A 12-month randomized controlled trial. Arch. Intern. Med. 2010, 170, 170-178. [CrossRef] [PubMed]

115. Cassilhas, R.C.; Viana, V.A.; Grassmann, V.; Santos, R.T.; Santos, R.F.; Tufik, S.; Mello, M.T. The impact of resistance exercise on the cognitive function of the elderly. Med. Sci. Sports Exerc. 2007, 39, 1401-1407. [CrossRef] [PubMed]

116. Liu-Ambrose, T.; Best, J.R.; Davis, J.C.; Eng, J.J.; Lee, P.E.; Jacova, C.; Boyd, L.A.; Brasher, P.M.; Munkacsy, M.; Cheung, W.; et al. Aerobic exercise and vascular cognitive impairment: A randomized controlled trial. Neurology 2016, 87, 2082-2090. [CrossRef]

117. Zimmer, P.; Bloch, W.; Schenk, A.; Oberste, M.; Riedel, S.; Kool, J.; Langdon, D.; Dalgas, U.; Kesselring, J.; Bansi, J. High-intensity interval exercise improves cognitive performance and reduces matrix metalloproteinases-2 serum levels in persons with multiple sclerosis: A randomized controlled trial. Mult. Scler. 2018, 24, 1635-1644. [CrossRef] [PubMed]

118. Morris, J.K.; Vidoni, E.D.; Johnson, D.K.; Van Sciver, A.; Mahnken, J.D.; Honea, R.A.; Wilkins, H.M.; Brooks, W.M.; Billinger, S.A.; Swerdlow, R.H.; et al. Aerobic exercise for Alzheimer's disease: A randomized controlled pilot trial. PLoS ONE 2017, 12, e0170547. [CrossRef]

119. Telenius, E.W.; Engedal, K.; Bergland, A. Effect of a high-intensity exercise program on physical function and mental health in nursing home residents with dementia: An assessor blinded randomized controlled trial. PLoS ONE 2015, 10, e0126102. [CrossRef] 
120. Barnes, D.E.; Santos-Modesitt, W.; Poelke, G.; Kramer, A.F.; Castro, C.; Middleton, L.E.; Yaffe, K. The Mental Activity and eXercise (MAX) trial: A randomized controlled trial to enhance cognitive function in older adults. JAMA Intern. Med. 2013, 173, 797-804. [CrossRef]

121. Park, H.; Park, J.H.; Na, H.R.; Hiroyuki, S.; Kim, G.M.; Jung, M.K.; Kim, W.K.; Park, K.W. Combined Intervention of Physical Activity, Aerobic Exercise, and Cognitive Exercise Intervention to Prevent Cognitive Decline for Patients with Mild Cognitive Impairment: A Randomized Controlled Clinical Study. J. Clin. Med. 2019, 8, 940. [CrossRef]

122. Vidoni, E.D.; Johnson, D.K.; Morris, J.K.; Van Sciver, A.; Greer, C.S.; Billinger, S.A.; Donnelly, J.E.; Burns, J.M. Dose-Response of Aerobic Exercise on Cognition: A Community-Based, Pilot Randomized Controlled Trial. PLoS ONE 2015, 10, e0131647. [CrossRef] 